\title{
The Impact of Fire Ants Solenopsis sp. on Upland Arthropods in Eastern India
}

\author{
Chitta Ranjan Satpathi \\ Bidhan Chandra Krishi Viswavidyalaya (State Agricultural University), Mohanpur, Nadia, West Bengal 741252, India
}

\begin{abstract}
Solenopsis sp. is an important invader on upland arthropod of Eastern India. This study was conducted to evaluate the role of this insect as potential biocontrol agent against some major pests of rice. The ant populations were sampled before and during appearance of hibernating larva and pupa of rice yellow stem borer (YSB) Scirpophaga incertulas (Walk.) inside the rice plant. Species richness and diversity of other ant species were also assessed from YSB protected field with insecticides and the crop grown under natural biological control. The maximum value of Barger-Parker index $(d=0.245)$ indicated that fire ant constituted $24.55 \%$ of the total population. Besides, in natural as in agricultural ecosystems, interference between fire ants and mealy bug as well as aphids was also recorded in different altitudes of the Eastern Himalayas and found that the incidence of fire ants Solenopsis sp. decreased the abundance of borer pests, but in contrast it increased the hopper pests in the same ecological niche.
\end{abstract}

Key words: Fire ant, Solenopsis sp., rice yellow stem borer, Barger-Parker index, mealy bug, aphid.

\section{Introduction}

The fire ant Solenopsis sp. (Hymenoptera: Formicidae) is an exotic species in Eastern India. It occupies many tropic position within agro-ecosystem, and feeds on variety of items, including seeds, nectars and insects. Below ground ants are known to fill an equally diverse set of ecological functions. From the previous study, it was found to directly increase predation in terrestrial system by $20 \%-30 \%$, and the predation includes not only pests, but also beneficial predators in cotton Gossypium hirsutum L., soybean Glycine $\max$ L. and Citrus Citrus spp. including beetles, lacewing and spiders $[1,2]$. Solenopsis geminata Fab. prayed on a wide variety of insects in rice field in Philippines. Even adult black bugs were subjected to predation by these strong aggressive insects [3]. The impact of fire ant Solenopsis sp. on upland arthropod in rice ecosystem in India was, however, largely overlooked. Over 100 species of insects attacked and damaged rice in India [4]. Many of them often appear sporadically, but do not cause

Corresponding author: Chitta Ranjan Satpathi, Ph.D., research field: agricultural entomology. economic loss. A few species, however, do cause significant damage and are extremely important. Among the different species, rice yellow stem borer (YSB) Scirpophaga incertulas (Walk.) is the most dominant and destructives in Eastern India [5, 6]. Arthropod pests and predator population in rice (Oryza sativa L.) fields are intimately associated with each other, yet there are few studies demonstrating how the abundance and diversity of fire ant Solenopsis sp. contribute to the biological control of YSB Scirpophaga incertulas (Walk.) at different growth stages of rice plant. The occurrence of terrestrial arthropod community in rice ecosystem is mainly influenced by the rice plant. The different communities of terrestrial arthropod in the rice field include rice pests, their natural enemies (predators and parasitoids) and other non-rice insect pests that inhabit or visit the vegetation. In the present investigation, only the impact of fire ant Solenopsis sp. on some above ground arthropods was studied in Eastern India. In addition, the evidence of commensalism between fire ant Solenopsis sp. and other insects were also recorded from different altitude of the Eastern Himalaya. 


\section{Materials and Methods}

The field experiments were conducted at Regional Research Station, Chakdaha, Bidhan Chandra Krishi Viswavidyalaya (BCKV), West Bengal, India during rainy seasons 2013-2014 and 2014-2015. The Regional Research Station was located at $20.5^{\circ}$ North latitude and $86.0^{\circ}-89.0^{\circ}$ East longitude with mean sea level rise $9.75 \mathrm{~m}$.

The experiment was carried out in strip plot design with three treatments (dates of transplanting) replicated seven times. Each plot was divided into two equal halves, one half was selected for natural biological control of stem borer and the remaining half for controlled condition. The controlled plots were kept free from stem borer infestation by using four rounds Chlorpyriphos 20\%CS@2 mL/liter of water or $375 \mathrm{~g}$ a.i./ha at $15 \mathrm{~d}$ interval from $21 \mathrm{~d}$ after transplanting. Three planting times were tested: the first planting time was $14 \mathrm{~d}$ before farmer's practice (July 12), the second planting time was simultaneous with farmer's practice (July 27) and the third planting time was $14 \mathrm{~d}$ after farmer's practice (August 12). The rice cultivar IET-4786 with standard short duration (110 d) was used in this experiment. Observations were recorded at weekly interval from randomly selected 10 sample hills on each plot.

The fire ants Solenopsis sp. populations were sampled before and during appearance of diapauses larva and pupa of YSB Scirpophaga incertulas (Walk.) inside the rice plant. The ant species diversity was analyzed in the both fields (natural biological control ant chemically protected field) through Simpson index [7] and Shannon-Weinner index [8], while abundance of species in each sample was assessed through Berger-Parker dominance index [9].

Besides, a separate survey study was conducted in Eastern Himalaya which is located in $20^{\circ} 31^{\prime \prime}-27^{\circ} 31^{\prime \prime}$ North latitude and $87^{\circ} 9^{\prime \prime}-88^{\circ} 53^{\prime \prime}$ East longitude, respectively. The Eastern Himalaya, in general, consists of steep hills, which is a part of Himalayan mountain range. The mountain spars of the Himalayas rises up from the plains to an altitude of $600-1,900 \mathrm{~m}$ above the mean sea level. The observations were recorded on commensalism between the red imported fire ant Solenopsis sp. and other insects, viz., mealy bug and aphid in different altitudes of hill.

\section{Results and Discussion}

\subsection{Factors Affecting the Population of Solenopsis sp.}

The population of Solenopsis sp. can affect YSB Scirpophaga incertulas (Walk.) in rice field. Mean population of fire ants Solenopsis sp. is usually affected by availability of larva and pupa inside the rice stem. In normal temperature $\left(20-25{ }^{\circ} \mathrm{C}\right)$, pupal stage lasted for $6 \mathrm{~d}$ to $10 \mathrm{~d}$, but in unfavorable condition (i.e., temperature below $15{ }^{\circ} \mathrm{C}$ or above $30{ }^{\circ} \mathrm{C}$ ), the pupa underwent diapauses. Of the later, about $30 \%$ to $40 \%$ population hibernated at lower internodes of rice plant in November and the adults emerged after transplanting the summer rice during the month of February. Sometimes the diapauses larva and pupae also found at the third or fourth internodes from the top. The population fluctuation of YSB Scirpophaga incertulas (Walk.) larva indicated 5-6 annual broods as given in Fig. 1.

Fig. 1 showed that the insect underwent diapauses in the 6th brood inside both matured rice plants and stubble during the month of November to February of every year. From this study, it was also recorded that about $80 \%$ rice plants in Eastern India usually become matured in the month of November. The larva and pupa of rice YSB become inactive in diapauses, because there is usually build up of reserve food substances in fat body and protein in haemolymph, with consequent reduction in the proportion of water.

The result is in agreement with Sula et al. [10], who reported diapauses associated with storage of protein accumulation in the haemolymph in adult Pyrrhocoris sp.. Before pupation, the larva makes an exit hole at lower internodes, through which the moth emerges. The observation is in accordance with Dale [11], who reported that pupation took place inside the stem, mostly 


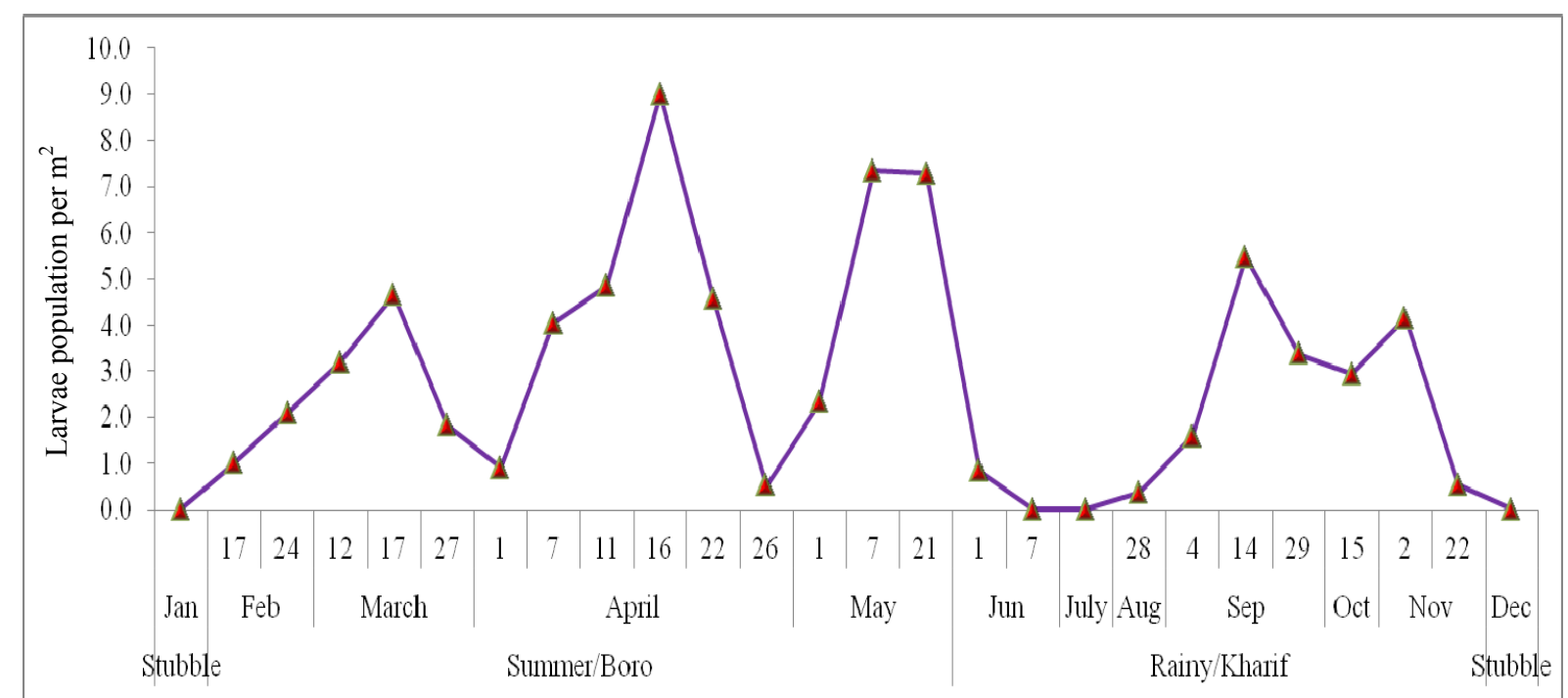

Fig. 1 Population fluctuation of stem borer larvae during consecutive two seasons during 2013-2014 and 2014-2015. Figure drawn on the basis of pulled data 2013-2014 and 2014-2015.

inside the lowest node of plant or just above the water level. The fire ant Solenopsis sp. usually enter inside the rice stem through this exit hole, and consume the hibernating larva and pupa, which ultimately affect the population build up of YSB in subsequent summer rice in Eastern India. The basic foods of Solenopsis sp. are fats, carbohydrates and protein that must be within reach. They usually get all of their sugar directly, but also are capable of transforming starch into sugar. For fat and proteins, the fire ants depend chiefly on insects in rice field. There was also limited body of evidence suggesting that Solenopsis sp. directly influence the population of YSB in rice field. But the population of this ant varied with the availability of diapauses larva and pupa of YSB in rice field, and this was examined by transplanting a well adopted variety of rice (IET 4786) on three different dates of transplanting with two different protections. The study evaluates the fire ant population over the course of two growing seasons in both the presence and absence of diapauses larva and pupa inside the rice stem and the results are given in Table 1.

The data on Table 1 suggest that the varied response of rice YSB was obtained with different dates of transplanting and their interactions. The main effect of dates of transplanting, protection treatment, and partial effect were significant at 5\% level. The population level of Solenopsis sp. gradually increased in similar succession as the dates of transplanting succeeded. The mean population on plants of the 1st, 2nd and 3rd dates of transplanting significantly differed statistically. The mean population of fire ants on plants of the 3 rd date of transplanting was higher than plants of the 1st and 2nd dates of transplanting. The treatment where the plants were protected with four rounds of Chlorpyriphos $20 \% \mathrm{CS}$ at $15 \mathrm{~d}$ interval had the lowest mean population regardless of date of transplanting, which was significantly different than the untreated plant. The interaction between dates of transplanting and protection treatment was also significant. The results are in agreement with Bessin and Reagan [12], who found a difference in infestation level Diatrea saccharalis (Fab.) (Lepidoptera: Pyralidae) caused by the predation of ant in Lausiana, USA. Vinson [13] assessed predation event as well as other tropic interaction, and found that in the presence of Solenopsis invicta Buren, the abundance of fly larva, sap beetle, rove beetles and parasitic wasps were significantly decreased. Number of workers have estimated the preying of cotton boll weevil pupa up to $85 \%$ by Solenopsis invicta in USA [14-16]. The authors also have recorded that critical fire ant density needed 
Table 1 Effect of different dates of transplanting with chemical protection of rice plant on population of Solenopsis sp. during 2013-2014 and 2014-2015.

\begin{tabular}{|c|c|c|c|c|c|c|c|c|c|c|c|}
\hline \multirow{4}{*}{ Dates of transplanting } & \multicolumn{11}{|c|}{ Average fire ant population/hill } \\
\hline & \multicolumn{5}{|c|}{$2013-2014$} & \multicolumn{6}{|c|}{$2014-2015$} \\
\hline & $80 \mathrm{DAT}$ & \multicolumn{2}{|c|}{$90 \mathrm{DAT}$} & \multicolumn{2}{|c|}{$110 \mathrm{DAT}$} & \multicolumn{2}{|c|}{$80 \mathrm{DAT}$} & \multicolumn{2}{|c|}{$90 \mathrm{DAT}$} & \multicolumn{2}{|c|}{110 DAT } \\
\hline & $\begin{array}{ll}\mathrm{P}_{0} & \mathrm{P}_{1} \\
\end{array}$ & $\mathrm{P}_{0}$ & $\mathrm{P}_{1}$ & $\mathrm{P}_{0}$ & $\mathrm{P}_{1}$ & $\mathrm{P}_{0}$ & $\mathrm{P}_{1}$ & $\mathrm{P}_{0}$ & $\mathrm{P}_{1}$ & $\mathrm{P}_{0}$ & $\mathrm{P}_{1}$ \\
\hline First date $\left(\mathrm{D}_{1}\right)$ & $8.0 \quad 0.0$ & 10.4 & 0.0 & 20.0 & 0.0 & 10.4 & 0.0 & 20.3 & 0.0 & 25.7 & 0.0 \\
\hline Second date $\left(\mathrm{D}_{2}\right)$ & $12.6 \quad 0.0$ & 23.7 & 0.0 & 32.9 & 0.0 & 20.7 & 0.0 & 38.7 & 0.0 & 50.9 & 0.0 \\
\hline \multirow[t]{2}{*}{ Third date $\left(\mathrm{D}_{3}\right)$} & $14.6 \quad 0.0$ & 85.1 & 0.0 & 119.7 & 0.0 & 25.7 & 0.0 & 65.9 & 0.0 & 142.7 & 0.0 \\
\hline & \multicolumn{11}{|c|}{ Average fire ant population of all plots after the same transplanting date } \\
\hline \multirow[t]{2}{*}{ Dates of transplanting } & \multicolumn{5}{|c|}{$2013-2014$} & \multicolumn{6}{|c|}{$2014-2015$} \\
\hline & $80 \mathrm{DAT}$ & \multicolumn{2}{|c|}{$90 \mathrm{DAT}$} & \multicolumn{2}{|c|}{$110 \mathrm{DAT}$} & \multicolumn{2}{|c|}{$80 \mathrm{DAT}$} & \multicolumn{2}{|c|}{$90 \mathrm{DAT}$} & \multicolumn{2}{|c|}{$110 \mathrm{DAT}$} \\
\hline First date $\left(\mathrm{D}_{1}\right)$ & 4.0 & \multicolumn{2}{|l|}{5.2} & \multicolumn{2}{|l|}{10.0} & \multicolumn{2}{|l|}{5.3} & \multicolumn{2}{|l|}{10.1} & \multicolumn{2}{|l|}{12.9} \\
\hline Second date $\left(\mathrm{D}_{2}\right)$ & 6.3 & \multicolumn{2}{|l|}{11.9} & \multicolumn{2}{|l|}{16.4} & \multicolumn{2}{|l|}{10.4} & \multicolumn{2}{|l|}{19.4} & \multicolumn{2}{|l|}{25.4} \\
\hline Third date $\left(\mathrm{D}_{3}\right)$ & 7.3 & \multicolumn{2}{|l|}{42.6} & 59.9 & & 12.9 & & 32.9 & & 71.4 & \\
\hline Protection treatment & & Avera & fire & oopulati & n of a & lots aft & the $\mathrm{s}$ & protec & on tre & & \\
\hline Natural protection $\left(\mathrm{P}_{0}\right)$ & 11.7 & 39.8 & & 57.5 & & 19.0 & & 41.6 & & 73.1 & \\
\hline $\begin{array}{l}\text { Chemical protection } \\
\left(\mathrm{P}_{1}\right)\end{array}$ & 0.0 & 0.0 & & 0.0 & & 0.0 & & 0.0 & & 0.0 & \\
\hline
\end{tabular}

Statistical analysis

\begin{tabular}{|c|c|c|c|c|c|c|c|c|c|c|c|c|}
\hline \multirow{3}{*}{ Effect } & \multicolumn{6}{|c|}{$2013-2014$} & \multicolumn{6}{|c|}{$2014-2015$} \\
\hline & \multicolumn{2}{|c|}{80 DAT } & \multicolumn{2}{|c|}{$90 \mathrm{DAT}$} & \multicolumn{2}{|c|}{$110 \mathrm{DAT}$} & \multicolumn{2}{|c|}{80 DAT } & \multicolumn{2}{|c|}{$90 \mathrm{DAT}$} & \multicolumn{2}{|c|}{$110 \mathrm{DAT}$} \\
\hline & SE & $\begin{array}{l}\text { CD } \\
(P=0.05)\end{array}$ & SE & $\begin{array}{l}\text { CD } \\
(P=0.05)\end{array}$ & SE & $\begin{array}{l}\text { CD } \\
(P=0.05)\end{array}$ & SE & $\begin{array}{l}\text { CD } \\
(P=0.05)\end{array}$ & SE & $\begin{array}{l}\text { CD } \\
(P=0.05)\end{array}$ & SE & $\begin{array}{l}\mathrm{CD} \\
(P=0.05)\end{array}$ \\
\hline DT & 0.30 & 0.87 & 4.12 & 11.90 & 5.30 & 15.30 & 1.92 & 5.54 & 4.43 & 12.80 & 8.83 & 25.50 \\
\hline Protection & 0.25 & 0.71 & 3.36 & 9.72 & 4.33 & 12.49 & 1.57 & 4.52 & 3.62 & 10.45 & 7.21 & 20.82 \\
\hline $\mathrm{DT} \times$ protection & 0.43 & 1.23 & 5.83 & 16.83 & 7.49 & 21.64 & 2.71 & 7.84 & 6.27 & 18.10 & 12.48 & 36.06 \\
\hline
\end{tabular}

$\mathrm{P}_{0}$ : Natural protection; $\mathrm{P}_{1}$ : chemical protection; DT: dates of transplanting; DAT: days after transplanting; SE: standard error; CD: critical difference.

to prevent economic damage by the boll weevil was 0.4 ants/10 plant terminal [14]. Besides, Solenopsis invicta Buren has long been recognized as an important predator assemblage preying on the egg, larva and pupal stage of sugarcane borer Diatrea saccharalis Fab. in USA $[17,18]$.

From the results, it can be concluded that the highest number of Solenopsis sp. in rice field varied considerably with population level of diapauses larva and pupa in rice field, but in general it can be concluded that Solenopsis sp. attacked, killed and consumed the insects that could not defend itself adequately or escape (Fig. 2).

\subsection{Species Diversity}

The effect of Solenopsis sp. on other ant species has been demonstrated in several studies, but crop stage wise diversity of different ant species in the field under natural biological control however was overlooked. The diversity indices of ant species in three different growth stages of rice crops are given in Table 2.

The data on Table 2 showed that both Simpson index of diversity $(D)$ and Berger-Parker index $(d)$ for fire ants had the highest value at ripening stage $(D=$ $12.048, d=0.245)$ and the lowest value at flowering stage $(D=4.237, d=0.240)$. Consequently, the Shannon-Weiver index $\left(H^{\prime}\right)$ was the highest in reproductive stage $\left(H^{\prime}=3.523\right)$ and the least in vegetative stage $\left(H^{\prime}=1.928\right)$. Therefore, it could be said that $D$ was influenced more by species richness where the population ranged from 9 adults/hill to 82 adults/hill. The value of Berger-Parker index $(d)$ indicated that most abundant species constituted $24.5 \%$ of total 


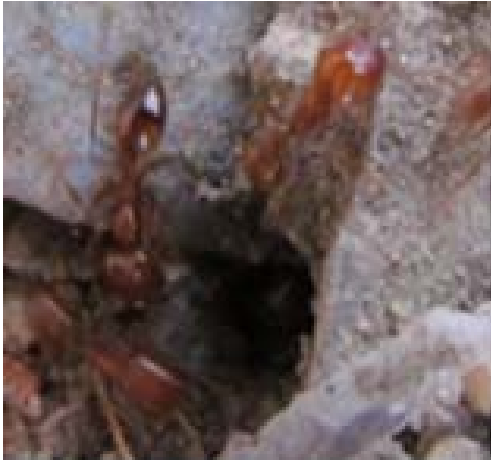

(a) Fire ant Solenopsis sp.

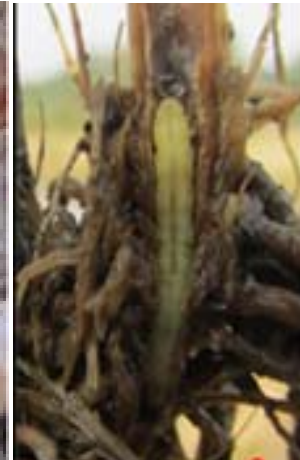

(b) YSB larva

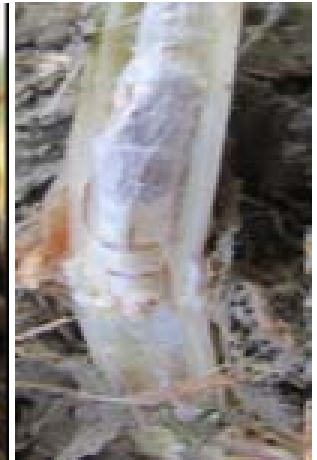

(c) YSB pupa

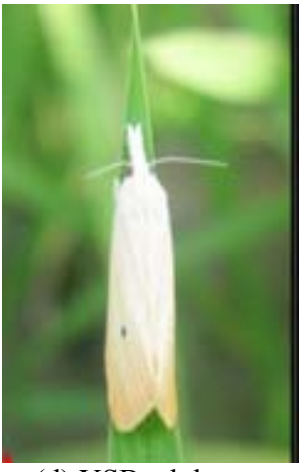

(d) YSB adult

Fig. 2 Photographs of fire ant (Solenopsis sp.) and larva, pupa and adult of YSB .

Table 2 Diversity indices of ant species in three different growth stages of rice crop in Eastern India.

\begin{tabular}{|c|c|c|c|c|c|c|c|}
\hline $\begin{array}{l}\text { Insect } \\
\text { (order/family) }\end{array}$ & Crop stage & $\begin{array}{l}\text { Total } \\
\text { abundance } \\
\text { of ant/hill }\end{array}$ & $\begin{array}{l}\text { Ant } \\
\text { population } \\
\text { range }\end{array}$ & $\begin{array}{l}\text { Simpson } \\
\text { index }(D)\end{array}$ & $\begin{array}{l}\text { Shannon } \\
\text {-Weiver } \\
\text { index }\left(H^{\prime}\right)\end{array}$ & $\begin{array}{l}\text { Berger- } \\
\text { Parker index } \\
\text { (d) }\end{array}$ & Dominant species \\
\hline \multirow{3}{*}{$\begin{array}{l}\text { Hymenoptera } \\
\text { (Formicidae) }\end{array}$} & $\mathrm{V}$ & 83 & $3-20$ & 6.211 & 1.928 & 0.241 & Diacoma vaganas Smith \\
\hline & $\mathrm{F}$ & 112 & $3-27$ & 4.237 & 2.122 & 0.240 & Camponotus compressus (F.) \\
\hline & $\mathrm{R}$ & 365 & $9-82$ & 12.048 & 3.523 & 0.245 & Solenopsis sp. \\
\hline
\end{tabular}

$\mathrm{V}=$ vegetative stage $\mathrm{F}=$ flowering stage $\mathrm{R}=$ ripening stage.

population. The dominancy of any single species in the community led to decline in community diversity. The result supported the observation in Ref. [19], where a positive correlation in percent occurrences of fire ant Solenopsis sp. was shown by the introduction of three ant species-Paratrechina longicornis Laterille, Pheidole moerens Wheeler and Tetramorium simillimum Smith, and one native species-Odontomachus brunneus Patton. In addition, the effect of Solenopsis invicta Buren on other ant species showed the direct predation on the nest of these other species [20]. In a similar study, the native fire ants Solenopsis geminata (F.) and Solenopsis xyloni Mc Cook have been displaced, as the invading imported species has spread across the South Eastern United States [21]. Other species displaced by imported fire ants include Pheidole tepicana Pergande and Pheidole crassicornis Wheeler [22].

\subsection{Interference of Solenopsis sp. on Other Insects in Eastern Himalayas}

A general survey on different altitude of Eastern Himalaya showed diverse habitat of Solenopsis sp. from plains to an altitude of $600 \mathrm{~m}$ to $1,900 \mathrm{~m}$ above mean sea level. Fire ants develop mutual relationship with different hopper pests, as they are able to produce honeydew, a sugary byproduct that primarily comprise simple sugars mixed with various free amino acid [23]. This honeydew is very attractive for fire ant, because it satisfies nutritional requirement that is fundamental for their colony growth and survive [24]. In the present investigation, the evidence of commensalism was recorded between fire ant Solenopsis sp. and mealy bug (Icerya sp., Brevennia rehi (Ldgr.)) as well as aphids (Rhopalosiphum sp., Aphis spp.) for their honeydews at $9.75 \mathrm{~m}$ and $600 \mathrm{~m}$ altitude, respectively. In exchange for honeydew, fire ants protect them from natural enemies and also reduce the abundance of interspecific competition for food and shelter (Fig. 3).

Similar observations were recorded by Wojcik [25], who reported that commensalism occurs between fire ant and other soil arthropod, including mites, millipedes, beetles, flies, hemipterans, parasitic wasps, butterflies, crickets and silverfish. Goetsch [26] also reported that the garden ants are known to have close 

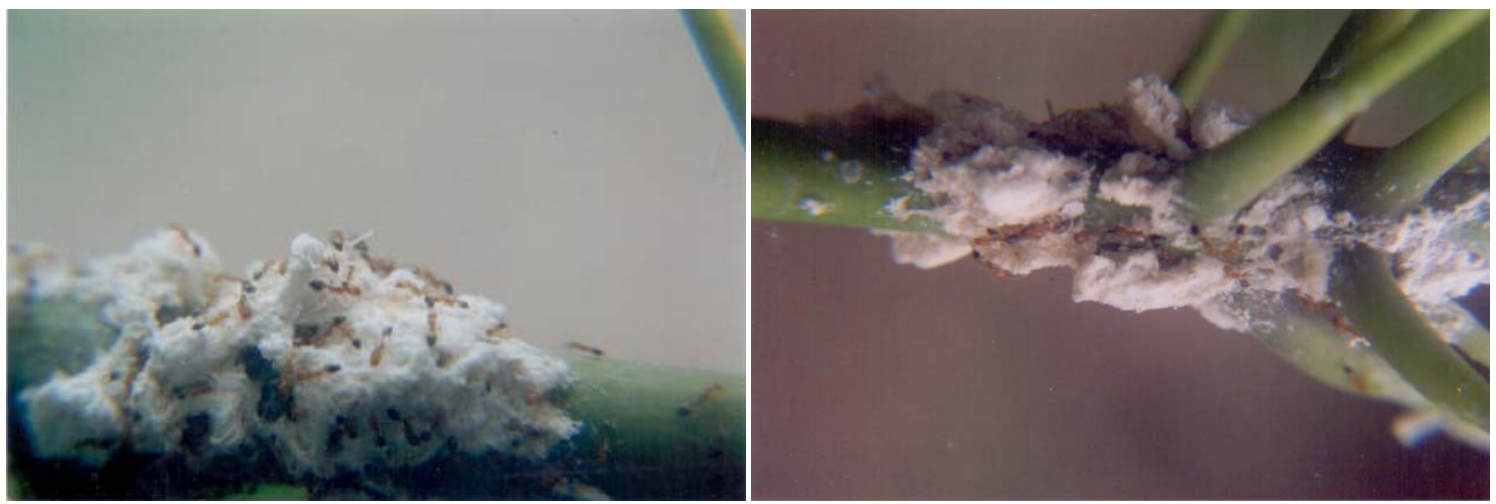

Fig. 3 Commensalism between Solenopsis sp. and mealy bug (Icerya sp.) at $600 \mathrm{~m}$ altitude Eastern Himalayas.

tie with plant lice. But, the widespread belief that the garden ant drives the plant lice out to pasture, like cows or carry them to their grazing grounds in trees or bushes, is not confirmed.

\section{Conclusions}

From the results of the experiment, it could be concluded that although the incidence of fire ants Solenopsis sp. decreased the abundance of some endemic pests, like YSB Scirpophaga incertuals (Walk.) in late planted rice crop, but in contrast, it increased the population of mealy bug and aphids in the same ecological niche. So the larger population of fire ant should be allowed in rice field as biocontrol agent when the hopper population remained below the economic threshold level.

\section{References}

[1] Eubanks, M. D. 2001. "Estimates of Direct and Indirect Effects of Red Imported Fire Ants on Biological Control in Field Crops." Biol. Control. 21 (1): 35-43.

[2] Eubanks, M. D., Blackwell, S. A., Parrish, C. J., Delamar, Z. D., and Hull-Sanders, H. 2002. "Intraguild Predation of Beneficial Arthropods by Red Imported Fire Ants in Cotton." Environ. Entomol. 31 (6): 1168-74.

[3] Shepard, B. M., Barion, A. T., and Litsinger, J. A. 1987. Friends of the Rice Farmer: Helpful Insect Spiders and Pathogens. Los Banos, Phillipines: IRRI, 136.

[4] Pathak, M. D. 1967. "Variety Resistance to Rice Stem Borer at International Rice Research Institute (IRRI)." In The Major Insect Pests of the Rice Plant. Baltimore, USA: The Johns Hopkins Press, 729.

[5] Directorate of Rice Research (DRR). 2003. Annual Progress Reports. All India Coordinated Rice
Improvement Project (AICRP), Directorate of Rice Research, Hyderabad, India.

[6] Satpathi, C. R., Chakraborty, K., Shikari, D., and Acharjee, P. 2012. "Consequence of Feeding by Yellow Stem Borer Scirpophaga incertulas (Walk.) on Rice Cultivar Swarna mashuri (MTU-7029)." World Appl. Sci. J. 17 (4): 532-9.

[7] Simpson, E. H. 1949. "Measurement of Diversity." Nature 163: 688.

[8] Shannon, C. E. 1948. "A Mathematical Theory of Communication." Bell System Technical Journal 27: 623-56.

[9] Southwood, T. R. E. 1978. Ecological Methods: With Particular Reference to the Study of Insect Population. Netherlands: Springer, 524.

[10] Sula, J., Kodrik, D., and Socha, R. 1995. "Hexamermis Haemolymph Protein Related to Adult Diapauses in the Red Firebug Pyrrhocoris apterus L. (Heteroptera)." Journal of Insect Physiology 41 (9): 793-800.

[11] Dale, D. 1994. "Insect Pests of the Rice Plant: Their Biology and Ecology." In Biology and Management of Rice Insect, edited by Heinrichs, E. A. New Delhi, India: Willey Eastern Limited, 364-485.

[12] Bessin, R. T., and Reagan, T. E. 1993. "Cultivar Resistance and Arthropod Predation of Sugarcane Borer (Lepidoptera: Pyralidae) Affects Incidence of Deadhearts in Louisiana Sugarcane." J. Econ. Entomol. 86 (3): 929-32.

[13] Vinson, S. B. 1991. "Effect of the Red Imported Fire Ant (Hymenoptera: Formicidae) on a Small Plant-Decomposing Arthropod Community." Environ. Entomol. 20 (1): 98-103.

[14] Fillman, D. A., and Sterling, W. L. 1983. "Killing Power of the Red Imported Fire Ant (Hymenoptera: Formicidae): A Key Predator of the Boll Weevil (Coleoptera: Curculionidae)." Entomophaga 28 (4): 339-44.

[15] Sterling, W. L. 1978. "Imported Fire Ant May Wear a Grey Hat.” Texas Agri. Progress 24: 19-20. 
[16] Strum, M. M., and Sterling, W. L. 1990. "Geographical Patterns of Boll Weevil Mortality: Observation and Hypothesis." Environ. Entomol. 19 (1): 59-65.

[17] Negam, A. A., and Hensley, S. D. 1969. "Evaluation of Certain Biological Control Agents of the Sugarcane Borer in Louisiana." J. Econ. Entomol. 62 (5): 1008-13.

[18] Reagan, T. E., Coburn, G., and Hensley, S. D. 1972. "Effects of Mirex on the Arthropod Fauna of a Louisiana Sugarcane Field." Environ. Entomol. 1 (5): 588-91.

[19] Wojcik, D. P. 1994. "Impact of the Red Imported Fire Ant on Native Ant Species in Florida." In Exotic Ants: Biology, Impact and Control of Introduced Species, edited by Williams, D. F. Boulder: Westview Press, 269-81.

[20] Hook, A. W., and Porter, S. D. 1990. "Destruction of Harvester Ant Colonies by Invading Fire Ants in South Central Texas (Hymenoptera: Formicidae)." Southwestern Nat. 35: 477-8.

[21] Porter, S. D. 1992. "Frequency and Distribution of
Polygyne Fire Ants (Hymenoptera: Formicidae) in Florida." Fla. Entomol. 75 (2): 248-57.

[22] Camilo, G. R., and Philips, S. A. 1990. "Evaluation of Ant Communities in Response to Invasion by the Fire Ant Solenopsis invicta Buren.” In Applied Myrmecology: A World Perspective, edited by Vander Meer, R. K., Jaffe, K., and Cedeno, A. Boulder: Westview, 190-8.

[23] Douglas, A. E. 1993. "The Nutritional Quality of Phloem Sap Utilized by Natural Aphid Population." Ecol. Entomol. 18 (1): 31-8.

[24] Hollodobler, B., and Wilson, E. O. 1990. The Ants. Cambridge, MA: Haward University Press.

[25] Wojcik, D. P. 1990. "Behavioral Interactions of Fire Ants and Their Parasites, Predators and Inquilines." In Applied Myrmecology: A World Perspective, edited by Vander Meer, R. K., Jaffe, K., and Cedeno, A. Boulder: Westview Press, 329-44.

[26] Goetsch, W. 1957. The Ants. Ann Arbor: The University of Michigan Press, 167. 